\title{
Need for Reframing of Prevention Strategies to Combat Opioid Epidemic
}

\section{To the Editor:}

We would like to comment on the manuscript published in JAMA by Busse et al titled "Opioids for Chronic Noncancer Pain: A Systematic Review and Meta-analysis" with a systematic review and metaanalysis (1). This systematic review and meta-analysis of opioids for chronic non-cancer pain suffers from highly variable and imperfect data. The review demonstrated that opioid use was associated with statistically significant but small improvements in pain and physical functioning alongside increased risk of vomiting compared with placebo. This is in agreement with previous systematic reviews providing limited or no evidence of effectiveness of opioids in chronic non-cancer pain $(2,3)$. Despite declining opioid prescriptions, opioid deaths continue to escalate. It is essential to refocus and redirect the effects of prevention of opioid abuse (4). Recent data from the CDC shows that escalating deaths are related mostly to synthetic opioids and heroin, with recent increase in deaths related to cocaine and methamphetamine, whereas, deaths due to natural and semi-synthetic opioids continue to be stable contributing to $20 \%$ of total drug-related deaths. In fact, prescription opioid-related deaths increased 18\% from 2009 to 2017 compared to $179 \%$ from 2001 to 2009. In contrast, fentanyl deaths increased $898 \%$ from 2009 to 2017 compared to $208 \%$ from 2001 to 2009.

It is interesting to note that to combat the opioid epidemic; some states are proposing medical marijuana as a substitute for opioids (5). It is ironic to note that marijuana is considered a gateway for the opioid epidemic. As currently reflected, opioids have become a gateway for the heroin and synthetic fentanyl epidemic.

Advocated for years, it is crucial to not overprescribe, and to take time to explain risks and harms to patients before they fill their first prescription. Redoubling efforts to improve the process of care when prescribing opioids may not be enough. Regulatory efforts are hindering appropriate management of pain by causing prescribers to without opioids which unfortunately can lead to withdrawal, and patient suicides. Extensive removal of opioids from patients who are dependent, may lead to illicit street purchasing of opioids. This is illustrated by a steady decline in opioid prescriptions of $22 \%$ from 2013 to 2017, yet stable prescription opioid deaths.

Laxmaiah Manchikanti, MD

Clinical Professor

Anesthesiology and Perioperative Medicine

University of Louisville, Louisville, Kentucky

Professor of Anesthesiology-Research

Department of Anesthesiology, School of Medicine LSU Health Sciences Center, New Orleans, Louisiana

Medical Director,

Pain Management Center of Paducah

67 Lakeview Drive

Paducah, KY 42001

Phone: 270-554-8373 ext. 4101

Fax: 270-554-8987

drlm@thepainmd.com

Alan D. Kaye, MD, PhD

Professor, Program Director, and Chairman

Department of Anesthesiology

Louisiana State University Health Science Center

1542 Tulane Ave, Room 659

New Orleans, LA 70112

akaye@Isuhsc.edu

Joshua A. Hirsch, MD

Vice Chief: Interventional Care

Massachusetts General Hospital

Associate Professor of Radiology,

Harvard Medical School

Affiliate Senior Research Fellow:

Neiman Health Care Policy Institute

55 Blossom St., Gray 241B

Boston, MA 02114

hirsch@snisonline.org 


\section{REFERENCES}

1. Busse JW, Wang L, Kamaleldin M, Craigie S, Riva JJ, Montoya L, Mulla SM, Lopes LC, Vogel N, Chen E, Kirmayr K, De Oliveira K, Olivieri L, Kaushal A, Chaparro LE, Oyberman I, Agarwal A, Couban R, Tsoi L, Lam T, Vandvik PO, Hsu S, Bala MM, Schandelmaier S, Scheidecker A, Ebrahim S, Ashoorion V, Rehman Y, Hong PJ, Ross S, Johnston BC, Kunz R, Sun X, Buckley N, Sessler DI, Guyatt GH. Opioids for chronic noncancer pain: A systematic review and meta-analysis. JAMA 2018; 320:2448-2460.

2. Manchikanti L, Kaye AM, Knezevic NN, McAnally $H$, Trescot AM, Blank S, Pampati V, Abdi S, Grider JS, Kaye AD,
Manchikanti KN, Cordner HJ, Gharibo CG, Harned ME, Albers SL, Atluri S, Aydin SM, Bakshi S, Barkin R, Benyamin RM, Boswell MV, Buenaventura RM, Calodney AK, Cedeno DL, Datta S, Deer TR, Fellows B, Galan V, Grami V, Hansen $\mathrm{H}$, Helm S 2nd, Justiz R, Koyyalagunta D, Malla Y, Navani A, Nouri K, Pasupuleti R, Sehgal N, Silverman SM, Simopoulos TT, Singh V, Slavin KV, Solanki DR, Staats PS, Vallejo R, Wargo BW, Watanabe A, Hirsch JA. Responsible, safe, and effective prescription of opioids for chronic non-cancer pain: American Society of Interventional Pain Physicians (ASIPP) guidelines. Pain Physician 2017; 20:S3-
S92.

3. Dowell D, Haegerich TM, Chou R. CDC Guideline for prescribing opioids for chronic pain - United States, 2016. JAMA 2016; 315:1624-1645.

4. Manchikanti L, Sanapati J, Benyamin RM, Atluri S, Kaye AD, Hirsch JA. Reframing the prevention strategies of the opioid crisis: Focusing on prescription opioids, fentanyl, and heroin epidemic. Pain Physician 2018; 21:309-326.

5. Voelker R. States Move to substitute opioids with medical marijuana to quell epidemic. JAMA. 2018;320(23):2408-2410. 